原

\title{
$\mathrm{ABC}$ 法を用いた各種血球表面の $\mathrm{A}$ 型物質の検索
}

\author{
足立 昌司12) 昚 隆吉12) 吉田 明憲 ${ }^{122}$ 椋本 芳樹1) \\ 山口 延男 ${ }^{2}$ ，堂脇 義雄 ${ }^{3)}$ \\ 1）神戸大学病院輸血部 \\ 2) 神戸大学医学部臨床検查医学 \\ 3）兵庫県赤十字血液センター
}

（昭和61年 7 月 30 日受付）

\section{DETECTION OF BLOOD GROUP A ANTIGEN ON HUMAN BLOOD CELLS USING THE AVIDIN-BIOTIN PEROXIDASE COMPLEX (ABC) METHOD}

\author{
Masashi Adachi*,**, Ryukichi Ryo*,**, Akinori Yoshida*,**, Yoshiki Mukumoto*, \\ Nobuo Yamaguchi** and Yoshio Douwaki*** \\ *Blood Transfusion Service, Kobe University Hospital \\ **Department of Laboratory Medicine, Kobe University School of Medicine \\ ***Hyougo Red Cross Blood Center
}

The blood group A antigen has been reported to exist on all blood cells's surface. However, the recent studies using the new immunological methods concluded that the A antigen could not be detected on neutrophils and monocytes.

Then we examined the presence of the A antigen on granulocytes, lymphocytes, monocytes, platelets and megakaryocytes using the mouse anti-A monoclonal antibody and the avidin-biotin peroxidase complex $(\mathrm{ABC})$ method.

By this method the A antigen could not be detected on neutrophils, eosinophils, basophils and monocytes.

The A antigen was weakly detected on lymphocytes from the group A secretor [ $\mathrm{Le}(\mathrm{a}-\mathrm{b}+)]$, but not on lymphocytes from the non-secretor $[\mathrm{Le}(\mathrm{a}+\mathrm{b}-)]$. The result indicated the $\mathrm{A}$ antigen (type $1 \mathrm{H}$ chain) on lymphocytes might be derived from the plasma. In contrast, the A antigen was strongly expressed on platelets, regardless of the A secretor status (type $1 \mathrm{H}$ chain, type $2 \mathrm{H}$ chain). Nevertheless, megakaryocytes which were the precursor cells of platelets, had no expression of the A antigens on the surfaces. We must consider when and how the A antigen on the surfaces of platelets come into existence.

\section{序霎}

従来, 血液型物質は赤血球, 顆粒球, リンパ球, 単球，および，血小板に存在すると考えられてい だ．しかし，血球表面の血液型物質の検索は直 接23)あるいは間接(4) 6)凝集反応, 吸収解離反 応 ${ }^{4) 7111)}$, 等によって行われていたので, 分離した 血球に他の血球成分，とくに赤血球の混入で誤っ た結論に導かれる可能性があった。近年, 抗原検 出のための鋭敏な方法であるフローサイトメト
リー, ラジオイムノアッセイ, 高感度の免疫組織 化学的手法が開発され, 䘏液型物質が顆粒球や単 球に存在しないことが明らかにされて，各種血球 表面の血液型物質の存在についての再検討がせま

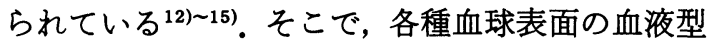
物質の有無を抗原検出のために免疫学的手法とし

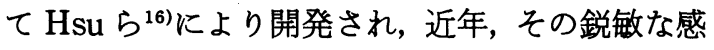
度と個々の細胞を検討できることで注目されてい る avidin-biotin peroxidase complex 法 (以下 
$\mathrm{ABC}$ 法)を用いて検討した。 また，抗原検出には マウスミェローマ細胞を用いて作製され，抗原と 強い親和性を有するモノクローナル抗体を用い て，血液型物質の局在の検索に際して誤判定のな いように工夫した。

\section{材料および方法}

抗体：抗Aモノクローナル抗体 (DAKO. Santa Barbara. Calif.) は，抗原として合成型物質であ る synsthetic trisaccharide alpha $\mathrm{D} \mathrm{N}$ acetyl galactosamine $(1-3)$ (alpha L Fuc $(1-2)$ ) beta D Gal（図 1) を使用して作製されたマウス

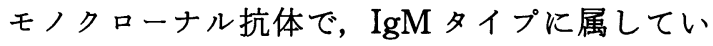
た。この抗体の力価は食塩水法で1,024倍であっ た. 抗体の希釈は, PBS で行い, 適時濃度を変え て用いた。

標本の作製：血球は， $\mathrm{A}$ 型の正常ドナーより得 られた末梢血と骨髄穿刺液の塗抹標本を用いた。 また，一部，へパリン加採血したあと赤血球拉よ び血小板は比重遠心法で分離し, リンパ球, 単球, ならびに顆粒球は Mono-poly Resolving Medium (M-PRM) (Dainihon Pharmaceutical Co., Osaka）を用いて分画し, PBS にて 2 回洗浄 後, Shandon Cytospin 2 (Shandon Ltd., England）で塗抹標本を作製した。

$\mathrm{ABC}$ 法：塗抹標本の固定は土タノール,アセト ン, ホルマリンアセトン, グルタールアルデヒド で行い, 内因性ペルオキシダーゼは $0.3 \% \mathrm{H}_{2} \mathrm{O}_{2}$ 加 PBS 中にて 30 分間浸漬して阻害した。 染色法は,

$<$ Immunogen for monoclonal anti A > GalNAc $\alpha 1 \rightarrow 3 \mathrm{Gal} \beta$

2

Fuc $\alpha 1$

$<$ Type 1 chain $\mathrm{A}>$

$$
\begin{aligned}
\text { GalNAc } \alpha 1 \rightarrow & 3 \mathrm{Gal} \beta 1 \rightarrow 3 \mathrm{GlcNAc} \beta 1 \rightarrow 3 \mathrm{Gal} \beta 1 \\
& 2 \\
& \uparrow \\
\text { Fuc } \alpha & 1
\end{aligned} \rightarrow 4 \mathrm{Glc} \rightarrow \mathrm{Cer}
$$

$<$ Type 2 chain $\mathrm{A}>$

GalNAc $\alpha 1 \rightarrow 3 \mathrm{Gal} \beta 1 \rightarrow 4 \mathrm{GlcNAc} \beta 1 \rightarrow 3 \mathrm{Gal} \beta 1$ $2 \quad \rightarrow 4 \mathrm{Glc} \rightarrow \mathrm{Cer}$

Fuc $\alpha 1$

図 1 抗A抗体の合成抗原
抗マウス IgM 用の $\mathrm{ABC}$ キット (Vector Labs., Burlingame, Calif）を用いて, 主として森ら ${ }^{17) の ~}$ 方法に従い染色した。 パックグランド值が上昇し ないよらに各ステップで十分にPBS で洗浄する ように留意した。発色は $0.3 \% \mathrm{H}_{2} \mathrm{O}_{2}$ 加 diaminobenzidin (DAB) (WAKO Pharmaceutical Co., Osaka）を用いて行ったのち，水 洗後, ギムザ液で核染し, 光顕でその反応の有無 を検討した。

\section{結 果}

$\mathrm{ABC}$ 法が血球表面の A 型物質を検出するのに どの程度鋭敏であるかを検討するために，抗A抗 体を128倍から1,024倍まで希釈して赤血球表面上 のA型物質の有無を検討してみると抗体の濃度に 応じた $\mathrm{A}$ 型物質の存在を示す強さの染色（褐色） を示した。この抗体の力価を食塩水法で検討する と $\mathrm{ABC}$ 法と同様に 1,024 倍で赤血球を凝集させ るので, 今回用いた $\mathrm{ABC}$ 法は極めて感度よく $\mathrm{A}$ 型物質を検出でさると考えられた。固定法は，エ タノール，アセトンおよびグルタールアルデヒド で良く染まり，ホルマリンアセトンでは染色性の 低下を認めた. 血小板表面も同様に1,024倍の抗体 でコントロールに比較してA型物質の存在を示す 染色を呈した.リンパ球表面のA型物質の有無は, 抗体128倍を用いて観察した． A 型分泌型の人 $[\mathrm{Le}$ $(a-b+)]$ ではリンパ球表面に図 2 に示したごと く僅かに陽性所見が認められA型物質の存在が示

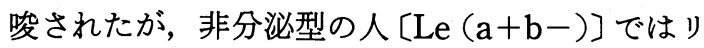
ンパ球表面にはまったく $\mathrm{A}$ 型物質を認めなかっ た。また，分泌型，非分泌型に拘らず，好中球に は抗体128倍で検索してもA型物質を認めず（困 3 ), 単球にも（図 4), 好塩基球にも（図 4）A 型物質は証明されなかった。好酸球は図 5 に示し たごとく顆粒が特異的に褐色に染まり，今回用い た方法で $\mathrm{A}$ 型物質の同定は困難であった. しかし， 赤血球, 血小板, リンパ球の $\mathrm{A}$ 型物質が血球表面 に存在して血球全体が抗原の存在を示す褐色に染 色されたが，好酸球では顆粒に一致して褐色を呈 したにも拘らず血球表面は染色されなかったので $\mathrm{A}$ 型物質は存在しないと判定した。な拉，ほ乳類 には存在しないグルコースオキシダーゼ反応を利 


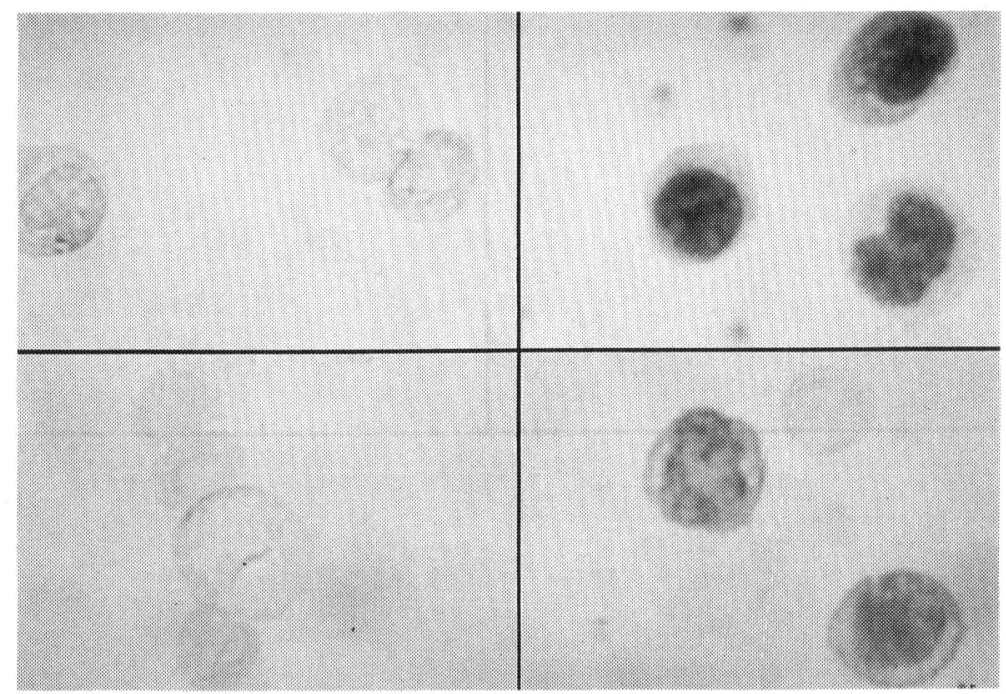

図 2 末梢リンパ球の $\mathrm{A}$ 型物質

左上：Le $(a-b+)$ の分泌型の人のリンパ球の抗 $\mathrm{A} モ$ ノクローナル抗体を用いた $\mathrm{ABC}$ 染色像, 陽性. 右上：同. $\mathrm{ABC}$ 染色後のギザム後染色像. 左下： $\operatorname{Le}(\mathbf{a}+\mathbf{b}-)$ の非分泌型の人のリンパ球の抗 $\mathrm{A} モ$ ノクローナル抗体を用いた $\mathrm{ABC}$ 染色像陰性. 赤 血球は陽性. 右下：同. $\mathrm{ABC}$ 染色後のギムザ後染色像.

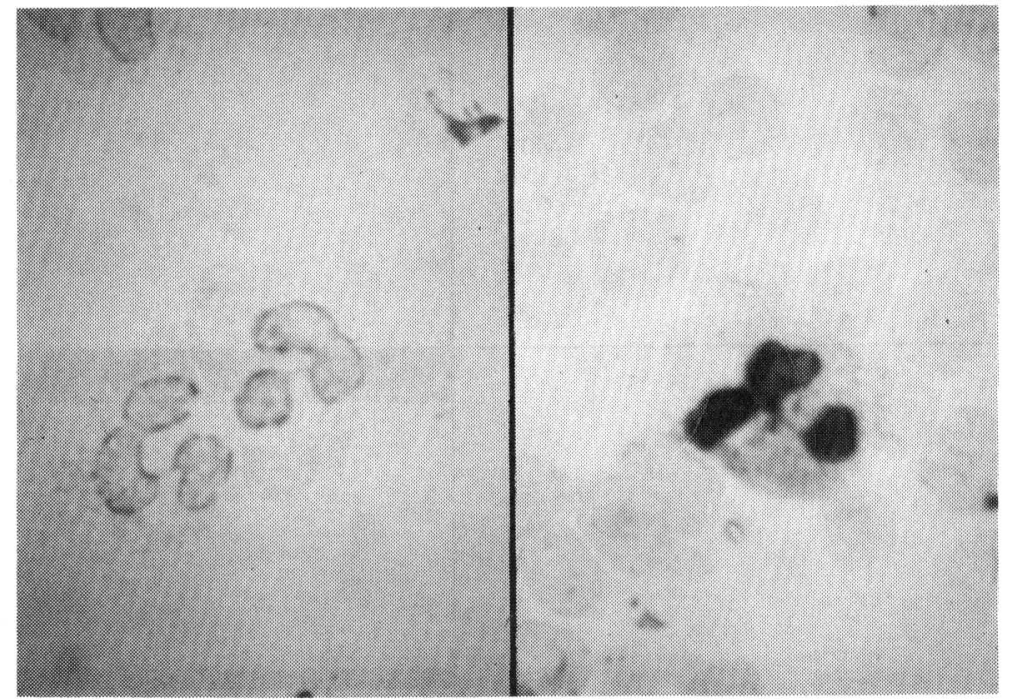

図 3 末梢好中球の $\mathrm{A}$ 型物質

左：抗 $\mathrm{A} モ$ クローナル抗体を用いた $\mathrm{ABC}$ 染色像, 陰性. 右： $\mathrm{ABC}$ 染色後のギムザ 後染色像.

用した $\mathrm{ABC}$ 法でも検討したが，顆粒の非特異的 反応は消失しなかった。骨髄塗抹標本の巨核球表 面は抗A抗体128倍に全く反応しなかった（図 6 )。 陽性コントロールとして血小板膜糖蛋白 IIb/IIIa
に対するモノクローナル抗体 $(224 \mathrm{~B})^{18)}$ で染色す ると，図6 右下に示したごとく巨核球は褐色を呈 し, 表面形質の性状を $\mathrm{ABC}$ 法で解析できるので,

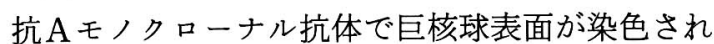




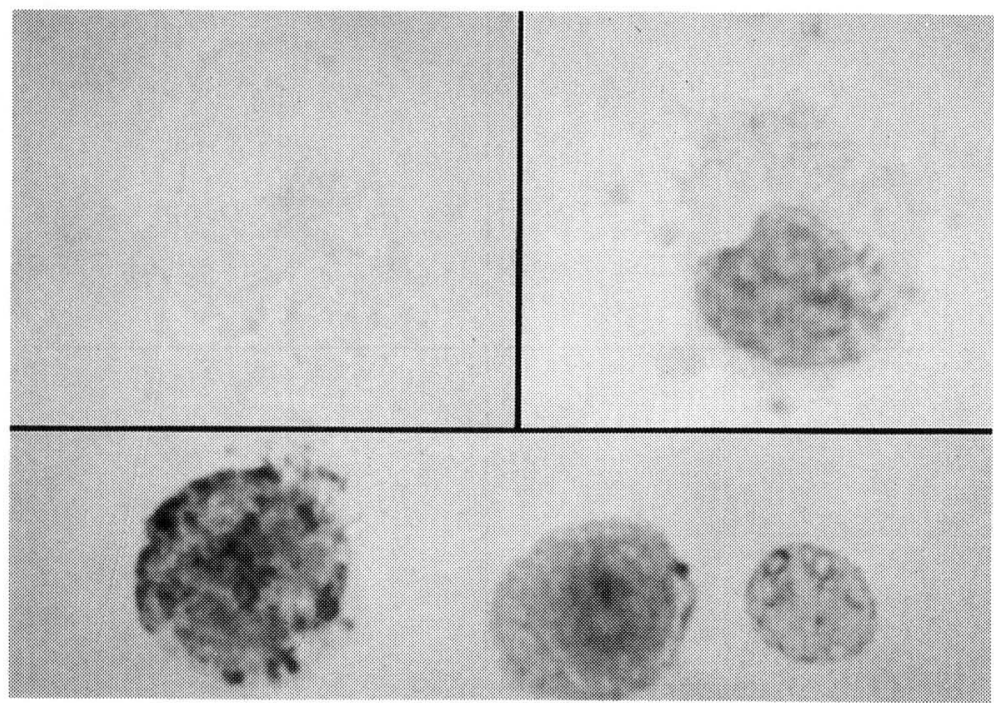

圀 4 単球掞よび好塩基球の $\mathrm{A}$ 型物質

左上：単球の抗 $\mathrm{A}$ ノクローナル抗体を用いた $\mathrm{ABC}$ 染色像, 陰性. 右上：同. $\mathrm{ABC}$

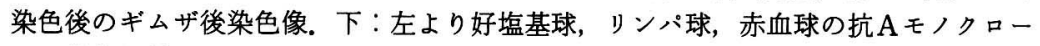
ナル抗体を用いた $\mathrm{ABC}$ およびギムザ後染色像. 好塩基球は陰性。リンパ球, 赤血球は 陽性.

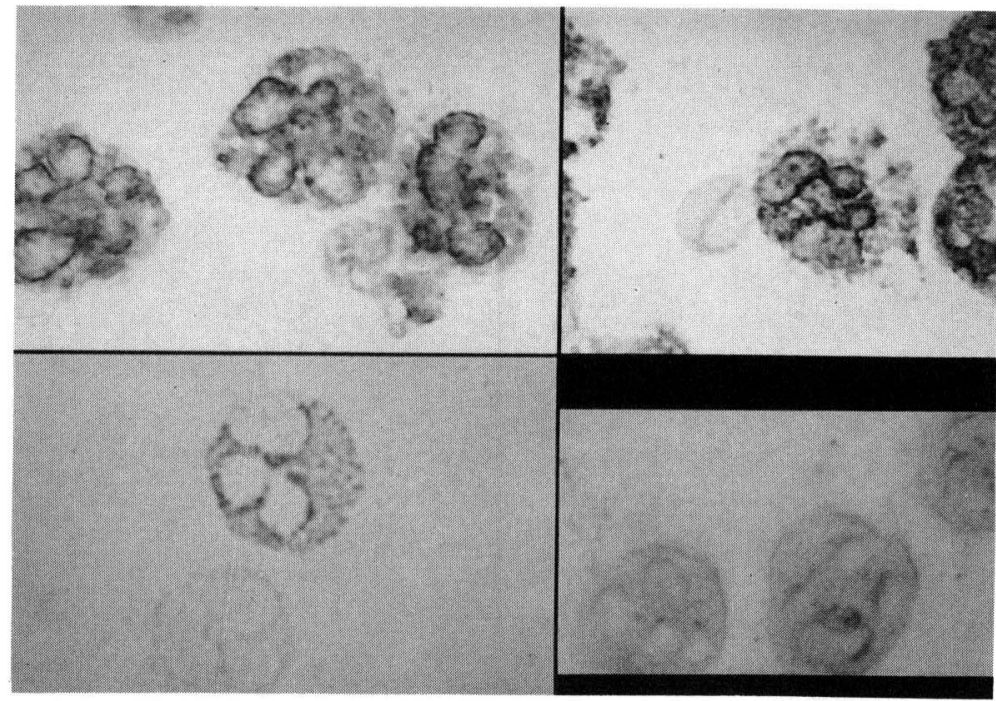

図 5 好酸球の $\mathrm{A}$ 型物質

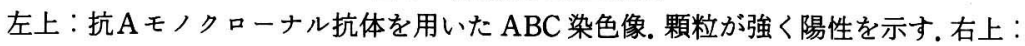
同. $\mathrm{ABC}$ 染色後のギムザ後染色像. 左下：ダルコースオキシダーゼ反応を利用した $\mathrm{ABC}$ 染色像. 上が好酸球で顆粒は陽性を示す。下は好中球. 右下：同. $\mathrm{ABC}$ 染色後 のギムザ後染色像.

ない所見は巨核球にA型物質が存在しないことを 示していると考えられた。
考 察

ABC 法は avidin と biotin 間の非可逆的で，通 常の抗原と抗体間の親和性よりはるかに高い親和 


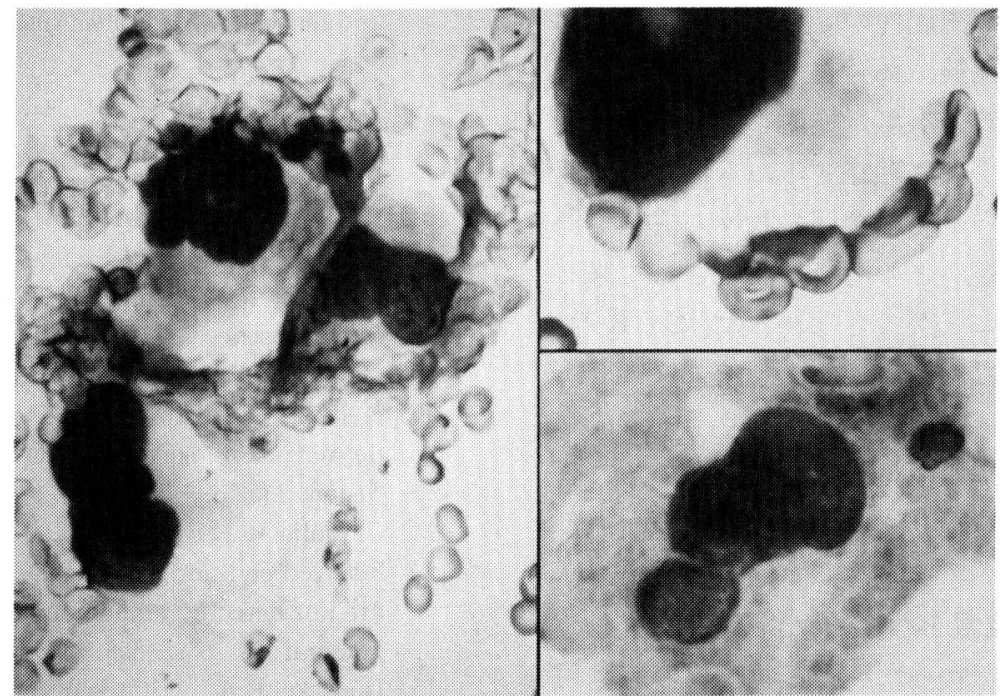

図 6 骨䯣巨核球の $\mathrm{A}$ 型物質

左：巨核球の抗 $\mathrm{A} モ$ ノクローナル抗体を用いた $\mathrm{ABC}$ およびギムザ後染色像, 陰性. 右 上：同. 払大像, 赤血球は陽性. 右下：血小板糖蛋白 IIb/IIIa モノクローナル抗体を 用いた $\mathrm{ABC}$ およびギムザ後染色像，陽性.

性を利用した特異性の高い免疫組織学的染色法で ある ${ }^{16)}$ 。この染色法のも5一つの特徴は細胞個々 の観察を行えることである. Henke ら ${ }^{199}$ は同法に て顆粒球表面上の HLA 抗原の有無を検索して良 い成績を報告している，今回我々はこの特徵を利 用して末梢血拉よび骨髄細胞の血液型物質の局在 の検討を行った。

従来, 血液型物質は赤血球を含む全ての血球に 存在すると考えられていた1)。しかし，1980年代に 入って, 好中球 ${ }^{12) 13) 14)}$ や単球 ${ }^{15)}$ に血液型物質が存 在しないことが，新しい免疫学的検出法で証明さ れるようになってきた。我々の成績も好中球や単 球に血液型物質が存在しないことを確認し, さら に，好酸球や好塩基球にも同様に血液型物質が無 いことを明らかにした。リンパ球に関しては，分 泌型の人のリンパ球にはA 型物質が認められ, 非 分泌型の人のリンパ球にはA 型物質が認められな

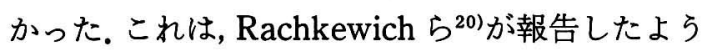
にリンパ球表面の血液型物質は血浆由来であるこ とを示していると考兄られた。

また，血小板にもA 型物質が存在していること が明らかになった。この血小板の血液型物質はリ
ンパ球と異なり分泌型あるいは非分泌型の何れに 扣いても存在していたので，血小板表面の $\mathrm{A}$ 型物 質は吸着したものではなく血小板表面で合成され たものと推定された，血小板に存在する型物質の 由来については諸家の研究報告がある. Kelton $ら^{21)}$ は赤血球血小板凝集反応で $\mathrm{O}$ 型の人の血小板 が $\mathrm{A}$ 型の人の血中の $\mathrm{A}$ 型物質を吸着することを示 したが，Dunstan ら 22)は Keltonらの用いた方法 は客観性，再現性にそしいことを指摘した。そし て, 彼らは ${ }^{125} \mathrm{I}$-標識抗ヒト IgGの binding assay 法を用いて血小板には血浆中から吸着される $1 \mathrm{H}$ 由来の糖脂質と, 赤血球膜で合成されるのと同様 な内因性に存在している2 $\mathrm{H}$ 由来の糖脂質 ${ }^{23224)} の$ 両血液型物質が存在することを明らかにし，血小 板の型物質は吸着と血小板自身により合成された ものの両者が関与している可能性を示唆した。

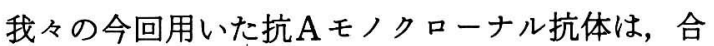
成型物質を抗原として作製しているので1H およ び2H 両者の由来の A 型物質を認識すると考えら れるので我々の成績からは血小板の $\mathrm{A}$ 型物質が吸 着したものか，血小板自身が有しているものかの 鑑別は困難であった。 そこで，我々は血小板表面 
に存在する型物質が内因性のものであれば，血小 板前駆細胞である巨核球に存在すると想定して巨 核球表面の $\mathrm{A}$ 型物質の有無を検討した。予測に反 してA型物質は血小板に存在するにも拘らず，巨 核球には全く認められず，今回の我々の成績では 血小板表面の型物質がどの時点で表現されて来る のか明らかにすることができなかった。ごく最近, Dunstan ら ${ }^{25}$ は，巨核球前駆細胞であるCFUMeg の血液型物質の検索を行い, コロニー形成し た巨核球が不均一に血液型物質を有していること を報告した。しかし，我々は，正常人 $\mathrm{AB}$ 型血浆 を用いてメチルセルロース法で培養した CFUMeg の型物質の検索を行なったが $\mathrm{A}$ 型物質を確 認することはできなかった ${ }^{26)}$.この成績の差は用 いた型物質に対する抗体の差に由来するのかもし れない，血小板の型物質の由来とどの時点で発現 されてくるかは今後の課題である.

\section{文献}

1）十字猛夫, 遠山 博, 他：輸血学. 中外医学社, 東京, 1978, 433 .

2) Wichels, P. and Lampe, W.: Die gruppenspezifische Differenzierung der Leukocyten. Klin Woscher, $7:$ 1741-1742, 1928.

3) Bakemeier, R.F. and Swisher, S.N.: Mixed agglutination of leukocytes and erythrocytes in relation to studies on leukocyte antigens. Blood, 12 : 913-925, 1957.

4) Gurner, B.W. and Coombs, R.R.A.: Examination of human leucocytes for the $\mathrm{ABO}, \mathrm{MN}, \mathrm{Rh}$ $\mathrm{Tj}^{\mathrm{a}}$, Lutheran and Lewis systems of antigens by means of a mixed erythrocyte-leucocyte agglutination. Vox Sang., 3 : 13-22, 1958.

5) Ashurst, D.E., Bedford, D. and Coombs, R.R.A. : Examination of human platelets for the ABO, $\mathrm{NM}, \mathrm{Rh}, \mathrm{Tj}^{\mathrm{a}}$, Lutheran and Lewis systems of antigens by means of mixed erythrocyteplatelet agglutination, Vox Sang., $1: 235,1956$.

6) Hellgren, H.M., Svardal, J.M. and Yunis, E.J. : Demonstration of $\mathrm{A}, \mathrm{B}$, and $\mathrm{Rh}$ antigens on human leukocytes. Transfusion, $6: 511,1966$.

7) Brittigham, T.E.: Immunologic studies on leukocytes. Vox Sang., 2: 242-248, 1957.

8) Anderson, R.E. and Walford, R.L.: Direct demonstration of $A, B$, and Rho(D) blood group antigens on human leukocytes. Amer. J. Clin. Path., 40 : 239-245, 1963.

9) Archer, G.T. and Kooptzoff, O.: Blood group antigens in white cells. Austral. J. Exp. Biol., $36: 373-382,1958$.

10) Lelezari, P. and Bernard, G. : Improved leukocyte antibody detection with prolonged incubation. Vox Sang., 9: 664-672, 1964.

11）安藤文英：血小板の A，B 型について，I，II，日 本輸血学会雑誌, $29: 1-18,1983$.

12) Dunstan, R.A., Simpson, M.B. and Borowitz, M.: Absence of $A B H$ antigen on neutrophils. Br. J. Haemat, 60 : 651-657, 1985.

13) Kelton, J.G. and Bebenex, G.: Granulocytes do not have surface $A B O$ antigens. Transfusion, 25 : 569-569, 1985.

14) Gaidulis, L., Branch, D.R. and Lazar, G.S. : The red cell antigens $\mathrm{A}, \mathrm{B}, \mathrm{D}, \mathrm{U}, \mathrm{Ge}, \mathrm{Jk} 3$ and $\mathrm{Yt}^{\mathrm{a}}$ are not detected on human granulocytes. Br. J. Haemat, 60: 659-668, 1985.

15) Dunstan, R.A.: Status of major red cell blood group antigens on neutrophils, lymphocytes and monocytes. Br. J. Haemat, 62 : 301-309, 1986.

16) Hus, S.M., Raine, L. and Fanger, H.: The use of avidin-biotin peroxidase complex (ABC) in immunoperoxidase techniques. J. Histochem. Cytochem, 29: 577-580, 1981.

17）森㫐由美, 在家裕司, 藤原睦憲, 森 茂郎：塗抹 標本に上る末梢血りンパ球マーカーの検索 II. $\mathrm{ABC}$ 法. 臨床血液, $26: 717-720,1985$.

18）吉岡 宗, 尞 隆吉: 抗人血小板膜モノクロナー ル抗体の作製。投稿中.

19) Henke, M., Yonemoto, L.M., Lazar, G.S., Gaidulis, L., Hecht, T., Santos, S. and Blume, K.G. : Visual detection of granulocyte surface antigens using the avidin-biotin complex. J. Histochem. Cytochem, 32: 712-716, 1984.

20) Rachkewich, R.A., Crookston, M.C., Tilley, C. A. and Wherrett, J.R.: Evidence that blood group A antigen on lymphocytes is derived from the plasma. J. Immunogenetics, $5: 25-29$, 1978.

21) Kelton, J.G., Hamid, C., Aker, S. and Blajchman, M.A.: The amount of blood group A substance on platelets is proportional to the amount in the plasma. Blood, 59: 980-985, 1982.

22) Dunstan, R.A.: The origin of $A B H$ antigens on human platelets. Blood, $65: 615-619,1985$.

23) Watkins, W.M. : Biochemistry and genetics of the $\mathrm{ABO}$, Lewis, and $\mathrm{P}$ blood group systems. Adv. Hum. Genet, 10, 1980.

24) Crookston, M.C.: Blood group antigens acquired from the plasma. Immunobiology of the 
Erythrocyte, Sandler SG, Nusbacker J, Schanfield MS(eds). New York, A.R. Liss, 1980, 99-114.

25) Dunstan, R.A.: The expression of $\mathrm{ABH}$ antigens during in vitro megakaryocyte maturation: Origin of heterogeneity of antigen density. Br. J. Haemat, 62 : 587-593, 1986.

26）足立昌司, 寮 隆吉：未発表データ. 